\title{
THE FORMATION OF DOME-SHAPED ICEBERGS
}

\author{
By FrITz LoEwe (Melbourne University, Australia)
}

DURING the recent cruise in Antarctic waters of the Australian National Antarctic Expedition's ship Wyatt Earp a great number of stranded bergs were seen on the shelf off the Ninnis Glacier tongue $\left(66^{\circ} \mathrm{S}\right.$. $147^{\circ} \mathrm{E}$.). Almost all these bergs had a dome-shaped or slightly conical outline, in contrast to the tabular shape of most floating bergs (see p. 282).

The dome-shaped "ice island bergs" of Priestley's classification, ${ }^{3}$ of which he,gives a quite characteristic photograph (Plate 287 , p. 580 ) have received a considerable amount of attention in Antarctic literature. Priestley ascribed their shape to the fact that the surface of the ice bodies from which they originated was not flat but consisted of "rolls." Recent air photographs give perfect examples of this roll formation, which is also represented in the same work (Plate 129, p. 525). ${ }^{3}$ If the bergs were detached along the troughs of these rolls, which would often form natural lines of weakness, their surface would have an elongated roll shape. This explanation does not, however, explain our observation that almost all of the dome-shaped bergs were evidently grounded, while the big floating bergs were of tabular shape.

Priestley suggested a possible alternative explanation, namely, that stronger melting near the edge would cause the sides of an originally tabular berg to droop; but he himself seemed doubtful of the significance of this explanation.

It may be argued that the dome shape of many stranded bergs is simply a consequence of their age. In a climate in which the snow line is at sea-level, stranded bergs might survive for hundreds of years. Deformation by plastic flow might then transform an originally box-like viscous body into one of dome shape. There is, however, no way to establish whether the time available is sufficient for such transformation.

Dome-shaped icebergs are very similar in their configuration to "island ice" covering a small island (p. I47) ${ }^{3}$ Examples of such island ice formations are frequently found in Antarctic literature, for instance Drygalski Island off Queen Mary Land. In a more advanced stage of glacierization, shelf ice might be formed around such an island, mainly by the accumulation of snow upon the sea ice attached to the island (Priestley's "shelf ice" of type 4 b).

In a paper just received Lamb ${ }^{2}$ is inclined to consider two dome-shaped masses in $64^{\circ} \mathrm{S}$., $100^{\circ}$ E. as glacierized islands or reefs. Lamb's description and Priestley's, ${ }^{3}$ Fig. 87 (p. r69), correspond completely with the appearance of the dome-shaped bergs we saw.

It seems very likely that the nucleus of these dome-shaped ice masses might be formed by a stranded berg as well as by a low-lying island. Incidentally, Priestley himself (p. I68) ${ }^{3}$ mentions the possibility of stranded bergs forming the anchoring points of shelf ice, but does not make this suggestion in connexion with dome-shaped bergs. According to this explanation the dome-shaped icebergs would not consist wholly of material detached from the continental ice-cap, but would represent small regions of independent glacierization. The climatic conditions off King George $\mathrm{V}$ Land do not appear incompatible with the position of the snow line in the immediate neighbourhood of sea-level which this explanation demands.

\section{R E F E R E N C E S}

1. Davis, John King. With the "Aurora" in the Antarctic r91 I-1914. London: Andrew Melrose, 1919.

2. Lamb, H. H. Notes on "Balaena's" observations on Southern Ice. Marine Observer (Meteorological Office Publication No. 493), Vol. 18, No. 139 , 1948, p. 34-41.

3. Wright, C. S. and Priestley, R. E. Glaciology. British (Terra Nova) Antarctic Expedition 1910-13. London: Harrison \& Sons, 1922. 